\title{
IMPLEMENTASI PENUGASAN DOSEN DI SEKOLAH (PDS) DALAM MATA KULIAH STRATEGI, METODE, DAN MEDIA PEMBELAJARAN BERBASIS LESSON STUDY
}

\author{
Dewi Ratnaningsih ${ }^{1}$ \\ ratnadewydj@gmail.com
}

\section{Universitas Muhammadiyah Kotabumi}

\begin{abstract}
After undergoing stage 1 PDS program, namely the implementation of lecturers to become "teachers" in schools, the next stage is the implementation of PDS within the university environment. The implementation of the PDS program phase 2 is realized in the Strategy, Method and Learning Media courses. The implementation of the PDS program in tertiary institutions is based on the principle of lesson study. Based on the results of the application, there are a number of lesson learns obtained. Lesson learns include: 1) giving material with appropriate learning media becomes a special attraction for students, 2) the formation of learning groups allows students to develop collaborative and communicative abilities, 3) assignments in the form of videos in the application of collaborative learning methods make students learn directly so a more maximal understanding process is obtained.
\end{abstract}

Key word: PDS, Lesson Study, Learning Media Method Strategies

Abstrak: Setelah menjalani program PDS tahap 1, yaitu pelaksanaan dosen menjadi "guru" di sekolah, tahap selanjutnya adalah implementasi PDS di lingkungan universitas. Implementasi program PDS tahap 2 diwujudkan dalam mata kuliah Strategi, Metode, dan Media Pembelajaran. Implementasi program PDS di Universitas didasarkan pada prinsip Lesson Study. Berdasarkan hasil implementasi, ada sejumlah lesson learn yang didapat. Lesson learn tersebut meliputi: 1) memberikan materi dengan media pembelajaran yang sesuai menjadi daya tarik khusus bagi siswa, 2) pembentukan kelompok belajar memungkinkan siswa untuk mengembangkan kemampuan kolaboratif dan komunikatif, 3) tugas dalam bentuk video dalam penerapan metode pembelajaran kolaboratif membuat siswa belajar secara langsung sehingga diperoleh proses pemahaman yang lebih maksimal.

Kata Kunci: PDS, Lesson Study, Strategi, Metode, Media Pembelajaran

\section{PENDAHULUAN}

Penugasan Dosen di Sekolah (selanjutnya disingkat PDS) merupakan sebuah program yang dicanangkan pemerintah dalam rangka memberikan pengalaman nyata bagi dosen LPTK. Dosen merupakan kunci utama dalam pendidikan guru. Dosen seharusnya memunyai modal pengalaman yang relevan dengan tuntutan kualitas pembelajaran di kelas. Dosen harus mampu menjadi model bagi mahasiswa sebagai calon guru. Oleh karena itu, dosen sebaiknya memunyai pengalaman langsung menjadi "guru" di sekolah. Hal ini dilakukan agar apa yang diajarkan dosen relevan dengan apa yang terjadi di sekolah. Program PDS adalah program yang sesuai 
dalam rangka memberikan dosen pengalaman nyata di sekolah.

Setelah menjalani program PDS tahap 1, yakni pelaksanaan dosen menjadi "guru" di sekolah, tahap selanjutnya adalah implementasi PDS dalam lingkungan perguruan tinggi. Tujuan dari program implementasi PDS yaitu: 1. Dosen menerapkan pengalaman terbaik ketika mengikuti program PDS pada tahun 2018 pada perkuliahan yang diampunya. 2. Dosen menerapkan hasil kemitraan dengan guru di sekolah pada PDS 2018 dalam perkuliahan yang diampunya. 3. Dosen menciptakan suasana yang mendukung peningkatan kualitas calon guru melalui perkuliahan yang diampunya. 4. Dosen meningkatkan kualitas pembelajaran pada program studi kependidikan dalam menunjang program pendidikan guru di LPTK (Direktorat Jendral Pembelajaran dan Kemahasiswaan Ristekdikti, 2019)

Kegiatan implementasi PDS secara umum adalah penerapan hasil dari program PDS dalam perkuliahan. Adapun lingkup kegiatannya meliputi: 1) Menyusun perangkat pembelajaran (RPS, media, bahan ajar dan alat evaluasi) yang berkualitas berdasarkan masukan dari kegiatan PDS tahun 2018. 2) Mengimplementasikan perangkat pembelajaran yang telah disusun. 3) Menerapkan pembelajaran inovatif yang mengembangkan critical thinking, creative thinking, communication, collaboration untuk berpikir tingkat tinggi. 4) Melakukan evaluasi pembelajaran (Direktorat Jendral Pembelajaran dan Kemahasiswaan Ristekdikti, 2019)

Implementasi program PDS di perguruan tinggi direalisasikan dalam mata kuliah Strategi, Metode, dan Media Pembelajaran. Mata kuliah ini berbobot 3 SKS. Tujuan dari mata kuliah ini adalah: 1) mengkaji hakikat dan makna strategi pembelajaran, 2) mengidentifikasi berbagai upaya dan menata faktor eksternal agar terwujud pembelajaran yang efektif dan efisien, 3) menganalisis taksonomi variabel dalam pembelajaran (tujuan pembelajaran dan karakteristik bidang studi, kendala, karakteristik peserta didik), 4) menganalisis dasar pertimbangan pemilihan strategi pembelajaran, pemanfaatan sumber belajar baik yang didesain maupun non desain untuk strategi pembelajaran pembelajaran, 5) menganalisis berbagai contoh penyusunan strategi pembelajaran dan contoh-contoh praktik terbaik dalam implementasi (best practice) tentang strategi pembelajaran, 6) memahami karakteristik internal peserta didik, dan upaya pembelajaran yang didasarkan pada teori belajar, 7) menganalisis kasus-kasus strategi pembelajaran di lapangan.

Proses pembelajaran dalam mata kuliah Strategi, Metode, dan Media Pembelajaran dilakukan dengan menerapkan prinsip Lesson Study. Prinsip lesson study 
dipilih karena melihat salah satu tujuan penerapan PDS yang mengarah pada peningkatan kemampuan kolaboratif. Lesson Study merupakan model pembinaan profesi pendidik melalui pengkajian pembelajaran secara kolaboratif dan berkelanjutan berdasarkan prinsip-prinsi kolegalitas dan mutual learning, serta membentuk learning comunity (Rusman, 2011). Lesson study merupakan salah satu cara untuk meningkatkan proses dan hasil pembelajaran yang dilakukan secara kolaboratif dan berkelanjutan (Sudrajad dalam Sandi, 2010). Lesson study merupakan sebuah proses pengembangan kompetensi profesional guru yang dikembangkan secara sistematis dalam sistem pendidikan di Jepang dengan tujuan utama menjadikan proses pembelajaran menjadi lebih baik dan efektif (Widhiartha dkk, 2008). Ratnaningsih (2018: 1) mengatakan bahwa lesson study merupakan suatu kegiatan pembinaan guru atau dosen untuk meningkatkan mutu pembelajaran.

Lesson Study merupakan proses pembelajaran secara kolaboratif. Ratnaningsih (2019: 22) mengatakan kegiatan kolaborasi antara guru dan dosen dapat berupa berbagi ide/pendapat,kerja sama, diskusi, interaksi, curah gagasan, dan membentuk komunitas belajar. Untuk mendapatkan hasil yang maksimal, terdapat lima unsur dalam pembelajaran kolaboratif. Lima unsur tersebut adalah: 1) salaing ketergantungan secara positif, 2) pertanggungjawaban individual, 3) kemampuan bersosialisasi, 4) tatap muka, dan 5) evaluasi/penilaian secara kelompok (Nurulhayati dalam Rusman, 2011). Kelima unsur tersebut tergambar dalam langkahlangkah pembelajaran lesson study. Adapun langkah-langkah penerapan lesson study terdiri atas: plan, do, dan see (Susilo, 2009). Hal yang sama juga dikemukakan oleh Putra dkk (2010) yang mengatakan bahwa lesson study ditopang oleh tiga pilar, yakni plan, do, dan see. Plan merupakan perencanaan atau perancangan proses pembelajaran. Hal ini dilakukan sebelum dilakukannya proses pembelajaran. Do merupakan pelaksanaan proses pembelajaran. Do terjadi di dalam atau di luar kelas. Do merupakan implementasi dari plan. See merupakan refleksi atau penilaian dari proses pembelajaran. See dilakukan diakhir pembelajaran. Setelah dilakukannya pengamatan dalam proses pembelajaran, pendidik melakukan penilaian dan refleksi untuk mendapatkan lesson learn. Berikut ini adalah skema kegiatan silkus lesson study.

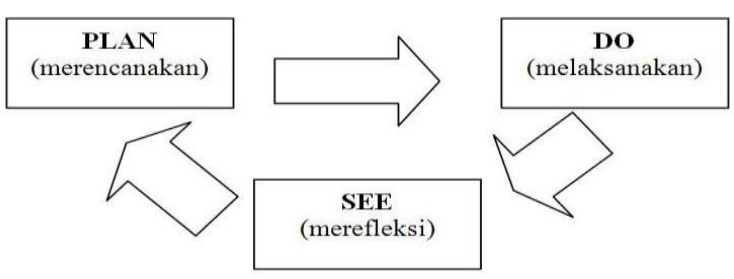

Gambar 1: Skema Kegiatan Lesson Study

Proses kolaborasi dalam lesson study terjadi antara: 1) dosen dengan dosen, 2) 
dosen dengan mahasiswa, dan 3) mahasiswa dengan mahasiswa. Kolaborasi antara dosen dengan dosen terjadi dalam penyusunan RPS ketika rapat pemantapan perangkat pembelajaran yang dilakukan setiap semester. Kolaborasi ini terjadi di tahap plan. Kolaborasi dosen dan mahasiswa terjadi dalam proses pembelajaran dikelas (do). Seperti halnya kolaborasi dosen dan mahasiswa, kolaborasi mahasiswa dengan mahasiswa juga terjadi di tahap do. Selanjutnya tahap see terjadi ketika perkuliahan telah selesai, dosen pengampu mata kuliah melakukan penilaian selama proses pembelajaran berlangsung dan disampaikan dalam rapat pementapan perangkat pembelajaran di semester berikutnya. Hal ini dilakukan untuk mendapatkan pengalaman terbaik atau best practice.

\section{Implementasi PDS dalam Mata Kuliah Strategi, Metode, dan Media Pembelajaran}

Lingkup kegiatan implementasi PDS meliputi: 1) penyusunan perangkat pembelajaran (RPS, media, bahan ajar dan alat evaluasi) yang berkualitas berdasarkan masukan dari kegiatan PDS tahun 2018. 2) pengimplementasian perangkat pembelajaran yang telah disusun. 3) penerapan pembelajaran inovatif yang mengembangkan critical thinking, creative thinking, communication, collaboration. 4) melakukan evaluasi pembelajaran (Direktorat Jendral Pembelajaran dan Kemahasiswaan Ristekdikti, 2019)

\section{Penyusunan Perangkat Pembelajaran (plan)}

Penyusunan perangkat pembelajaran dilakukan sebelum dosen pengampu melakukan proses mengajar di kelas. Penyusunan perangkat pembelajaran dilakukan dengan memperhatikan masukan dari kegiatan PDS sebelumnya. Masukan tersebut meliputi: 1) proses pembelajaran secara kolaboratif relevan digunakan dalam pembelajaran di sekolah. Oleh karena itu, pemahaman tentang metode pembelajaran yang bersifat kolaborasi harus diberikan kepada mahasiswa. 2) metode pembelajaran TAI releven digunakan ketika guru ingin menilai kemampuan individu siswa melalui penerapan pembelajaran kolaborasi. 3) metode pembelajaran yang relevan diajarkan kepada mahasiswa meliputi metode integratif, kuantum, kontrustivistik (STAD, TAI, CIRC, Jigsaw, GI, Learning Together, dan beberapa metode kolaboratif lainnya. Berdasarkan masukan dari kegiatan PDS sebelumnya, dirancanglah sebuah rencana pembelajaran semester dengan memasukkan materi terkait metode di atas, selain tetap memperhatikan panduan materi di buku panduan akademik yang ada. 


\section{Implementasi Perangkat Pembelajaran (do)}

Proses implementasi perangkatan pembelajaran (dalam hal ini RPS) yang telah disusun dilakukan selama satu semester. jumlah pertemuan selama 16 kali. Proses pembelajaran dilakukan sebanyak 14 kali karena 2 pertemuan digunakan untuk UTS dan UAS. Berikut ini adalah tabel rincian pembelajaran selama satu semester.

Berdasarkan ketentuan di perguruan tinggi

\begin{tabular}{|c|c|c|c|}
\hline $\begin{array}{l}\text { Minggu } \\
\text { ke }\end{array}$ & $\begin{array}{c}\text { Capaian } \\
\text { Pembelajaran } \\
\text { Perkuliahan }\end{array}$ & Indikator & Materi Ajar \\
\hline 1. & $\begin{array}{l}\text { Setelah mempelajari } \\
\text { dan mengikuti } \\
\text { tutorial mata kuliah } \\
\text { ini, mahasiswa } \\
\text { diharapkan } \\
\text { memahami dan } \\
\text { mempunyai } \\
\text { kompetensi tentang } \\
\text { pengertian makna } \\
\text { dan hakekat dan } \\
\text { lingkup dan tujuan } \\
\text { kegiatan Strategi } \\
\text { Pembelajaran. }\end{array}$ & $\begin{array}{l}\text { Mahasiswa dapat: } \\
\text { 1. Menjelaskan } \\
\text { pengertian strategi } \\
\text { pembelajraan } \\
\text { 2. Mengetahui perbedaan } \\
\text { strategi, metode, } \\
\text { teknik, taktik } \\
\text { pembelajaran }\end{array}$ & $\begin{array}{l}\text { Pengertian strategi } \\
\text { pembelajraan, Perbedaan } \\
\text { strategi, metode, teknik, } \\
\text { taktik pembelajaran }\end{array}$ \\
\hline 2. & $\begin{array}{l}\text { Setelah mempelajari } \\
\text { dan mengikuti } \\
\text { tutorial mata kuliah } \\
\text { ini, mahasiswa } \\
\text { diharapkan } \\
\text { memahami dan } \\
\text { mempunyai } \\
\text { kompetensi tentang } \\
\text { pengertian dan jenis- } \\
\text { jenis metode } \\
\text { pembelajaran. }\end{array}$ & $\begin{array}{l}\text { Mahasiswa dapat: } \\
\text { 1. Menjelaskan pengertian } \\
\text { metode pembelajaran } \\
\text { 2. Menjelaskan jenis-jenis } \\
\text { metode pembelajaran }\end{array}$ & $\begin{array}{l}\text { Pengertian metode } \\
\text { pembelajaran, jenis-jenis } \\
\text { metode pembelajaran }\end{array}$ \\
\hline 3. & $\begin{array}{l}\text { Setelah mempelajari } \\
\text { dan mengikuti } \\
\text { tutorial mata kuliah } \\
\text { ini, mahasiswa } \\
\text { diharapkan } \\
\text { memahami dan } \\
\text { mempunyai } \\
\text { kompetensi tentang } \\
\text { prosedur penerapan } \\
\text { metode tata } \\
\text { Bahasa/terjemahan }\end{array}$ & $\begin{array}{l}\text { Mahasiswa dapat : } \\
\text { 1. Menjelaskan prosedur } \\
\text { atau langkah-langkah } \\
\text { pembelajaran dengan } \\
\text { metode tata Bahasa/ } \\
\text { terjemahan } \\
\text { 2. Menerapkan metode } \\
\text { pembelajaran tersebut }\end{array}$ & $\begin{array}{l}\text { Menjelaskan prosedur } \\
\text { atau langkah-langkah } \\
\text { pembelajaran dengan } \\
\text { metode tata Bahasa/ } \\
\text { terjemahan, Menerapkan } \\
\text { metode pembelajaran } \\
\text { tersebut }\end{array}$ \\
\hline 4. & $\begin{array}{l}\text { Setelah mempelajari } \\
\text { dan mengikuti }\end{array}$ & $\begin{array}{l}\text { Mahasiswa dapat: } \\
\text { 1. Menjelaskan prosedur }\end{array}$ & $\begin{array}{l}\text { Menjelaskan prosedur } \\
\text { atau langkah-langkah }\end{array}$ \\
\hline
\end{tabular}




\begin{tabular}{|c|c|c|c|}
\hline $\begin{array}{c}\text { Minggu } \\
\mathrm{ke}\end{array}$ & $\begin{array}{c}\text { Capaian } \\
\text { Pembelajaran } \\
\text { Perkuliahan }\end{array}$ & Indikator & Materi Ajar \\
\hline & $\begin{array}{l}\text { tutorial mata kuliah } \\
\text { ini, mahasiswa } \\
\text { diharapkan } \\
\text { memahami dan } \\
\text { mempunyai } \\
\text { kompetensi tentang } \\
\text { prosedur penerapan } \\
\text { metode membaca } \\
\end{array}$ & $\begin{array}{l}\text { atau langkah-langkah } \\
\text { pembelajaran dengan } \\
\text { metode membaca } \\
\text { 2. Menerapkan metode } \\
\text { pembelajaran tersebut }\end{array}$ & $\begin{array}{l}\text { pembelajaran dengan } \\
\text { metode membaca, } \\
\text { Menerapkan metode } \\
\text { pembelajaran tersebut }\end{array}$ \\
\hline 5. & $\begin{array}{l}\text { Setelah mempelajari } \\
\text { dan mengikuti } \\
\text { tutorial mata kuliah } \\
\text { ini, mahasiswa } \\
\text { diharapkan } \\
\text { memahami dan } \\
\text { mempunyai } \\
\text { kompetensi tentang } \\
\text { prosedur penerapan } \\
\text { metode audiolingual }\end{array}$ & $\begin{array}{l}\text { Mahasiswa dapat: } \\
\text { 1. Menjelaskan prosedur } \\
\text { atau langkah-langkah } \\
\text { pembelajaran dengan } \\
\text { metode audiolingual } \\
\text { 2. Menerapkan metode } \\
\text { pembelajaran tersebut }\end{array}$ & $\begin{array}{l}\text { Menjelaskan prosedur } \\
\text { atau langkah-langkah } \\
\text { pembelajaran dengan } \\
\text { metode audiolingual, } \\
\text { Menerapkan metode } \\
\text { pembelajaran tersebut }\end{array}$ \\
\hline 6. & $\begin{array}{l}\text { Setelah mempelajari } \\
\text { dan mengikuti } \\
\text { tutorial mata kuliah } \\
\text { ini, mahasiswa } \\
\text { diharapkan } \\
\text { memahami dan } \\
\text { mempunyai } \\
\text { kompetensi tentang } \\
\text { prosedur penerapan } \\
\text { metode langsung }\end{array}$ & $\begin{array}{l}\text { Mahasiswa dapat: } \\
\text { 1. Menjelaskan prosedur } \\
\text { atau langkah-langkah } \\
\text { pembelajaran dengan } \\
\text { metode langsung } \\
\text { 2. Menerapkan metode } \\
\text { pembelajaran tersebut }\end{array}$ & $\begin{array}{l}\text { Menjelaskan prosedur } \\
\text { atau langkah-langkah } \\
\text { pembelajaran dengan } \\
\text { metode langsung, } \\
\text { Menerapkan metode } \\
\text { pembelajaran tersebut }\end{array}$ \\
\hline 7. & $\begin{array}{l}\text { Setelah mempelajari } \\
\text { dan mengikuti } \\
\text { tutorial mata kuliah } \\
\text { ini, mahasiswa } \\
\text { diharapkan } \\
\text { memahami dan } \\
\text { mempunyai } \\
\text { kompetensi tentang } \\
\text { prosedur penerapan } \\
\text { metode komunikatif }\end{array}$ & $\begin{array}{l}\text { Mahasiswa dapat: } \\
\text { 1. Menjelaskan prosedur } \\
\text { atau langkah-langkah } \\
\text { pembelajaran dengan } \\
\text { metode komunikatif } \\
\text { 2. Menerapkan metode } \\
\text { pembelajaran tersebut }\end{array}$ & $\begin{array}{l}\text { Menjelaskan prosedur } \\
\text { atau langkah-langkah } \\
\text { pembelajaran dengan } \\
\text { metode komunikatif, } \\
\text { Menerapkan metode } \\
\text { pembelajaran tersebut }\end{array}$ \\
\hline 8. & \multicolumn{3}{|c|}{ UTS } \\
\hline 9. & $\begin{array}{l}\text { Setelah mempelajari } \\
\text { dan mengikuti } \\
\text { tutorial mata kuliah } \\
\text { ini, mahasiswa } \\
\text { diharapkan } \\
\text { memahami dan } \\
\text { mempunyai } \\
\text { kompetensi tentang }\end{array}$ & $\begin{array}{l}\text { Mahasiswa dapat: } \\
\text { 1. Menjelaskan prosedur } \\
\text { atau langkah-langkah } \\
\text { pembelajaran dengan } \\
\text { metode integratif } \\
\text { 2. Menerapkan metode } \\
\text { pembelajaran tersebut }\end{array}$ & $\begin{array}{l}\text { Menjelaskan prosedur } \\
\text { atau langkah-langkah } \\
\text { pembelajaran dengan } \\
\text { metode integratif } \\
\text { menerapkan metode } \\
\text { pembelajaran tersebut }\end{array}$ \\
\hline
\end{tabular}




\begin{tabular}{|c|c|c|c|}
\hline $\begin{array}{c}\text { Minggu } \\
\mathrm{ke}\end{array}$ & $\begin{array}{c}\text { Capaian } \\
\text { Pembelajaran } \\
\text { Perkuliahan }\end{array}$ & Indikator & Materi Ajar \\
\hline & $\begin{array}{l}\text { prosedur penerapan } \\
\text { metode integratif }\end{array}$ & & \\
\hline 10. & $\begin{array}{l}\text { Setelah mempelajari } \\
\text { dan mengikuti } \\
\text { tutorial mata kuliah } \\
\text { ini, mahasiswa } \\
\text { diharapkan } \\
\text { memahami dan } \\
\text { mempunyai } \\
\text { kompetensi tentang } \\
\text { prosedur penerapan } \\
\text { metode tematik }\end{array}$ & $\begin{array}{l}\text { Mahasiswa dapat: } \\
\text { 1. Menjelaskan prosedur } \\
\text { atau langkah-langkah } \\
\text { pembelajaran dengan } \\
\text { metode tematik } \\
\text { 2. Menerapkan metode } \\
\text { pembelajaran tersebut }\end{array}$ & $\begin{array}{l}\text { Menjelaskan prosedur } \\
\text { atau langkah-langkah } \\
\text { pembelajaran dengan } \\
\text { metode tematik } \\
\text { Menerapkan metode } \\
\text { pembelajaran tersebut }\end{array}$ \\
\hline 11. & $\begin{array}{l}\text { Setelah mempelajari } \\
\text { dan mengikuti } \\
\text { tutorial mata kuliah } \\
\text { ini, mahasiswa } \\
\text { diharapkan } \\
\text { memahami dan } \\
\text { mempunyai } \\
\text { kompetensi tentang } \\
\text { prosedur penerapan } \\
\text { metode kuantum }\end{array}$ & $\begin{array}{l}\text { Mahasiswa dapat: } \\
\text { 1. Menjelaskan prosedur } \\
\text { atau langkah-langkah } \\
\text { pembelajaran dengan } \\
\text { metode kuantum } \\
\text { 2. Menerapkan metode } \\
\text { pembelajaran tersebut }\end{array}$ & $\begin{array}{l}\text { Menjelaskan prosedur } \\
\text { atau langkah-langkah } \\
\text { pembelajaran dengan } \\
\text { metode kuantum, } \\
\text { Menerapkan metode } \\
\text { pembelajaran tersebut }\end{array}$ \\
\hline 12. & $\begin{array}{l}\text { Setelah mempelajari } \\
\text { dan mengikuti } \\
\text { tutorial mata kuliah } \\
\text { ini, mahasiswa } \\
\text { diharapkan } \\
\text { memahami dan } \\
\text { mempunyai } \\
\text { kompetensi tentang } \\
\text { prosedur penerapan } \\
\text { metode } \\
\text { kontruktivistik } \\
\text { (STAD dan TAI) }\end{array}$ & $\begin{array}{l}\text { Mahasiswa dapat : } \\
\text { 1. Menjelaskan prosedur } \\
\text { atau langkah-langkah } \\
\text { pembelajaran dengan } \\
\text { metode kontruktivistik } \\
\text { (STAD dan TAI) } \\
\text { 2. Menerapkan metode } \\
\text { pembelajaran tersebut }\end{array}$ & $\begin{array}{l}\text { Menjelaskan prosedur } \\
\text { atau langkah-langkah } \\
\text { pembelajaran dengan } \\
\text { metode kontruktivistik } \\
\text { (STAD dan TAI), } \\
\text { Menerapkan metode } \\
\text { pembelajaran tersebut }\end{array}$ \\
\hline 13. & $\begin{array}{l}\text { Setelah mempelajari } \\
\text { dan mengikuti } \\
\text { tutorial mata kuliah } \\
\text { ini, mahasiswa } \\
\text { diharapkan } \\
\text { memahami dan } \\
\text { mempunyai } \\
\text { kompetensi tentang } \\
\text { prosedur penerapan } \\
\text { metode } \\
\text { kontruktivistik } \\
\text { (CIRC dan Jigsaw) }\end{array}$ & $\begin{array}{l}\text { Mahasiswa dapat: } \\
\text { 1. Menjelaskan prosedur } \\
\text { atau langkah-langkah } \\
\text { pembelajaran dengan } \\
\text { metode kontruktivistik } \\
\text { (CIRC dan JIgsaw) } \\
\text { 2. Menerapkan metode } \\
\text { pembelajaran tersebut }\end{array}$ & $\begin{array}{l}\text { Menjelaskan prosedur } \\
\text { atau langkah-langkah } \\
\text { pembelajaran dengan } \\
\text { metode kontruktivistik } \\
\text { (CIRC dan JIgsaw), } \\
\text { Menerapkan metode } \\
\text { pembelajaran tersebut }\end{array}$ \\
\hline 14. & Setelah mempelajari & Mahasiswa dapat & Menjelaskan prosedur \\
\hline
\end{tabular}




\begin{tabular}{|c|c|c|c|}
\hline $\begin{array}{c}\text { Minggu } \\
\text { ke }\end{array}$ & $\begin{array}{c}\text { Capaian } \\
\text { Pembelajaran } \\
\text { Perkuliahan }\end{array}$ & Indikator & Materi Ajar \\
\hline & $\begin{array}{l}\text { dan mengikuti } \\
\text { tutorial mata kuliah } \\
\text { ini, mahasiswa } \\
\text { diharapkan } \\
\text { memahami dan } \\
\text { mempunyai } \\
\text { kompetensi tentang } \\
\text { prosedur penerapan } \\
\text { metode } \\
\text { kontruktivistik (LG } \\
\text { dan GI) }\end{array}$ & $\begin{array}{l}\text { 1. } \begin{array}{l}\text { Menjelaskan prosedur } \\
\text { atau langkah-langkah } \\
\text { pembelajaran dengan } \\
\text { metode kontruktivistik }\end{array} \\
\text { (LG dan GI) } \\
\text { 2. Menerapkan metode } \\
\text { pembelajaran tersebut }\end{array}$ & $\begin{array}{l}\text { atau langkah-langkah } \\
\text { pembelajaran dengan } \\
\text { metode kontruktivistik } \\
\text { (LG dan GI), Menerapkan } \\
\text { metode pembelajaran } \\
\text { tersebut }\end{array}$ \\
\hline 15. & $\begin{array}{l}\text { Setelah mempelajari } \\
\text { dan mengikuti } \\
\text { tutorial mata kuliah } \\
\text { ini, mahasiswa } \\
\text { diharapkan } \\
\text { memahami dan } \\
\text { mempunyai } \\
\text { kompetensi untuk } \\
\text { menyusun media ajar } \\
\text { yang menarik dan } \\
\text { berbasis teknologi }\end{array}$ & $\begin{array}{l}\text { Mahasiswa dapat: } \\
\text { 1. Membuat media ajar } \\
\text { yang relevan dan } \\
\text { menarik berbasisi } \\
\text { teknologi } \\
\text { 2. Menerapkan media } \\
\text { pembelajaran tersebut }\end{array}$ & $\begin{array}{l}\text { Membuat media ajar yang } \\
\text { relevan dan menarik } \\
\text { berbasisi teknologi, } \\
\text { Menerapkan media } \\
\text { pembelajaran tersebut }\end{array}$ \\
\hline 16. & \multicolumn{3}{|c|}{ UAS } \\
\hline
\end{tabular}

Dari tabel di atas, diketahui bahwa proses pemberian materi tentang metode pembelajaran mendominasi materi. Hal ini terjadi karena salah satu tujuan dari pembelajaran mata kuliah Strategi, Metode, dan Media Pembelajaran adalah mahasiswa memahami dan mampu menerapkan berbagai metode pembelajaran di sekolah. Pemberian materi terkait metode pembelajaran yang bersifat kolaboratif juga menjadi penekanan lebih. Hal ini didasari dari hasil refleksi pelaksanaan PDS sebelumnya. Berdasarkan jurnal refleksi guru dan dosen pada pelaksanaan PDS sebelumnya, pembelajaran yang bersifat kolaboratif sangat relevan digunakan dalam proses belajar mengajar di kelas.

\section{Penerapan Pembelajaran Inovatif yang Mengembangkan Critical Thinking, Creative Thinking, Communication, Collaboration (do)}

Pembelajaran inovatif yang dipilih dalam proses pembelajaran pada mata kuliah Strategi, Metode, dan Media Pembelajaran adalah pembelajaran yang bersifat kolaborasi. Penerapan pembelajaran yang bersifat kolaboratif dilakukan dengan menerapkan prinsip lesson study. Melalui lesson study, mahasiswa dapat belajar secara kelompok. Penulis selaku dosen pengampu 
mata kuliah memberikan pemahaman konsep di awal pembelajaran. Setelah pemberian konsep pada pertemuan satu dan dua, dosen meminta mahasiswa untuk membentuk kelompok. Pembentukan kelompok dilakukan berdasarkan materi yang telah disusun. Setiap kelompok akan membahas materi yang berbeda. Materi tersebut merupakan materi-materi mengenai metode pembelajaran kolaboratif. Setelah dibentuknya kelompok, mahasiswa menyusun makalah terkait metode tertentu. Selain itu, mahasiswa harus mampu menerapkan metode pembelajaran yang sedang dibahas dalam bentuk video pembelajaran. Berdasarkan pembagian materi yang telah diberikan, mahasiswa membuat simulasi penerapan metode pebelajaran. Dari beberapa anggota kelompok, salah satu mahasiswa akan menjadi guru dan menerapkan metode pembelajaran tersebut. Berikut ini merupakan gambaran pelaksanaan lesson study dalam mata kuliah Strategi, Metode, dan Media Pembelajaran.

\section{Gambar 1}

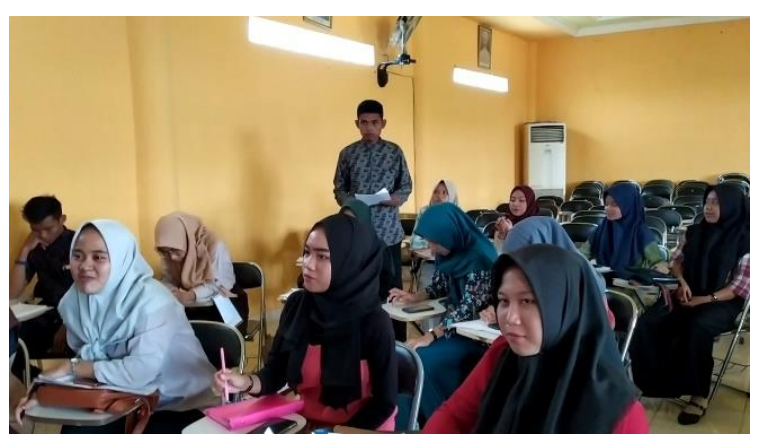

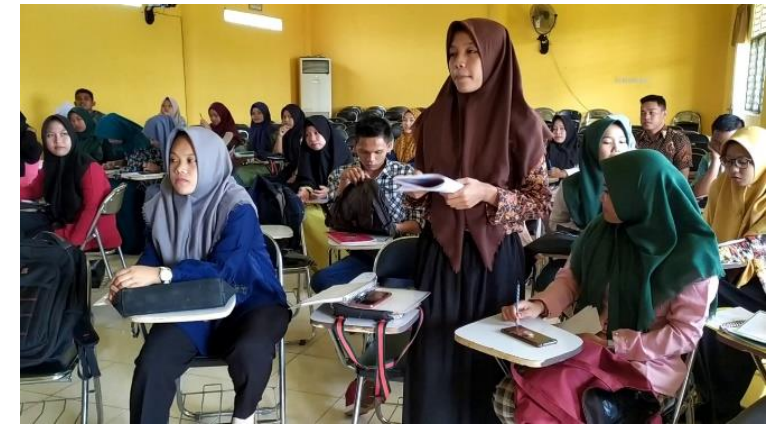

Gambar 1 merupakan gambar pelaksanaan pembelajaran yang bertujuan untuk mengembangkan critical thingking mahasiswa. Critical thingking terjadi ketika mahasiswa mampu berpikir secara kritis memberikan tanggapan terhadap materi yang diberikan. Proses terbentuknya critical thingking dapat dilakukan dengan memberikan stimulus kepada mahasiswa. Stimulus yang diberikan dapat berupa pertanyaan atau pemberian kesempatan kepada mahasiswa untuk memberikan pendapat terkait materi yang sedang dipelajari. 
Gambar 2
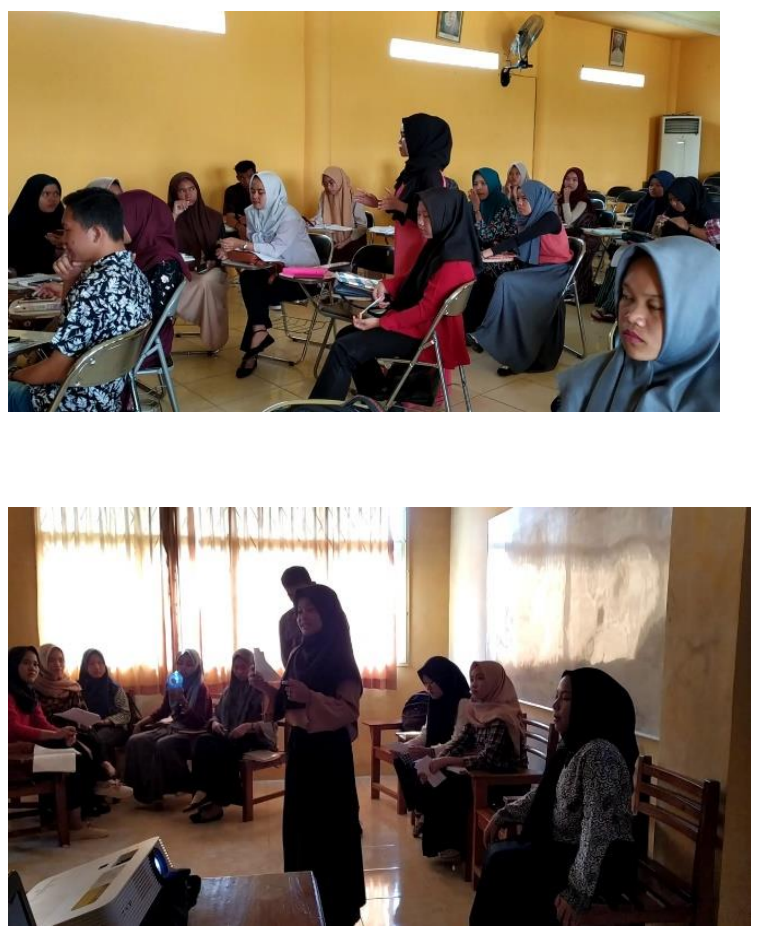

Gambar 2 merupakan gambar pelaksanaan pembelajaran yang bertujuan untuk mengembangkan creative thingking mahasiswa. Creative thingking terjadi ketika mahasiswa mampu memberikan tanggapan yang bersifat inovasi terhadap materi yang diberikan. Creative thingking akan terbentuk jika dosen memberikan stimulus yang relevan. Mahasiswa diberikan kebebasan untuk memecahkan 'kasus' pembelajaran dalam kelas. Hal ini dilakukan sebagai upaya untuk menciptakan dan menilai kreativitas berpikir mahasiswa dalam memecahkan permasalahan dalam kegiatan belajar mengajar di kelas.
Gambar 3
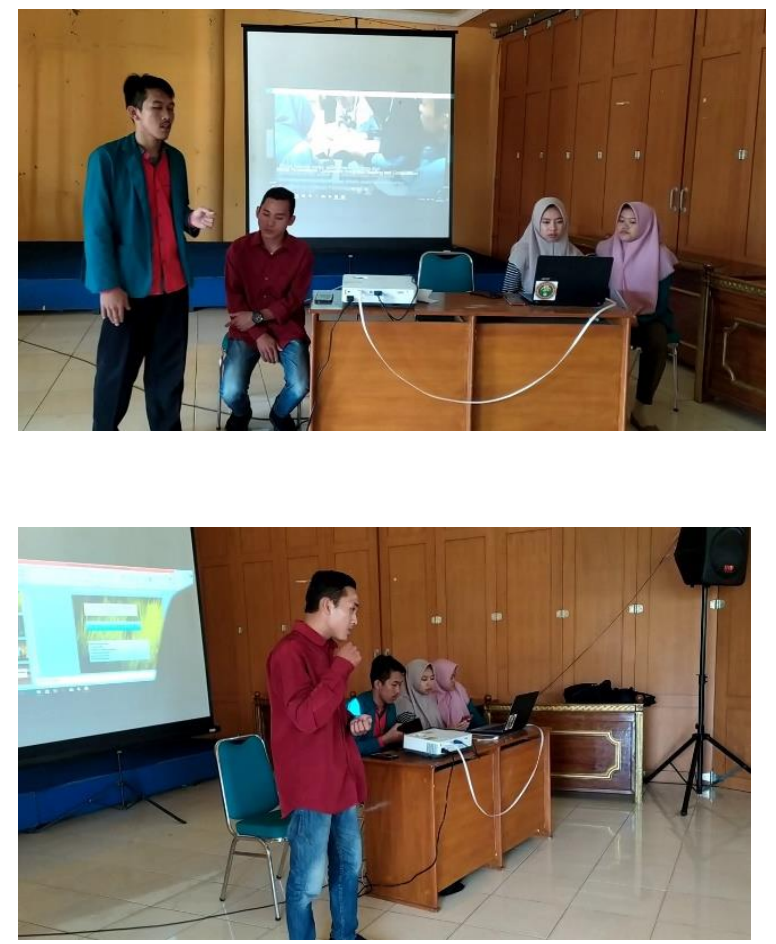

Gambar 3 merupakan gambar pelaksanaan pembelajaran yang bertujuan untuk mengembangkan aspek comunication mahasiswa. Comunication terjadi ketika mahasiswa mampu menjelaskan, mempresentasikan, dan memberikan tanggapan terhadap materi. Terbentuknya kemampuan komunikasi yang baik dari setiap mahasiswa menjadi suatu tujuan pembelajaran yang wajib ditekankan. Sebagai seorang calon guru, mahasiswa wajib memunyai kemampuan komunikasi yang baik dan benar. 
Gambar 4
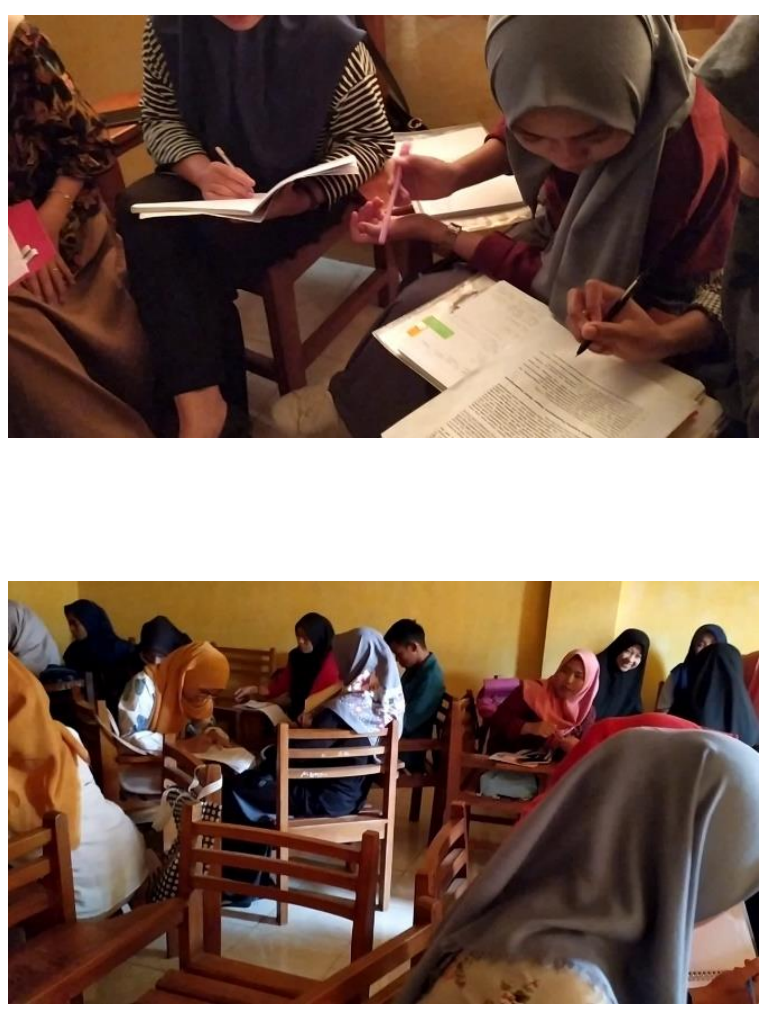

Gambar 4 merupakan gambar pelaksanaan pembelajaran yang bertujuan untuk mengembangkan aspek collaboration mahasiswa. Collaboration terjadi ketika mahasiswa mampu bekerja sama dalam kelompoknya. Konteks kerja sama meliputi pembuatan materi, presentasi kelompok, dan pembuatan video pembelajaran.

\section{Melakukan Evaluasi Pembelajaran (see)}

Setelah rangkaian pembelajarn terjadi, tahap terakhir yang dilakukan adalah melakukan proses evaluasi. Evaluasi atau penilaian dalam pembelajaran dilakukan dengan melakukan proses análisis segala hal yang terjadi dalam proses pembelajaran. Catatan lapangan dari dosen pengampu menjadi sebuah dasar sebuah refleksi pembelajaran berikutnya. Berdasarkan catatan lapangan/hasil observasi selama dalam proses pembelajaran terjadi, terdapat sebuah lesson learn dari implementasi PDS melalui prinsip lesson study. Lesson learn yang diperoleh adalah: 1) pemberian materi dengan media pembelajaran yang tepat menjadi daya tarik tersendiri bagi mahasiswa, 2) pembentukan kelompok belajar memungkinkan mahasiswa untuk mengembangkan kemampuan kolaboratif dan komunikatif, 3) pemberian tugas berupa video penerapan metode pembelajaran kolaboratif membuat mahasiswa belajar secara langsung sehingga proses pemahaman lebih maksimal diperoleh.

Beberapa temuan pembelajaran yang didapat menjadi sebuah dasar untuk didiskusikan dalam kegiatan refleksi (see). Tahap refleksi terjadi ketika dosen pengampu mata kuliah melakukan sharing dengan dosen lain dalam rapat pemantapan perangkat pembelajaran di setiap semester. hal-hal tersebut dikemukakan sebagai bahan untuk perbaikan proses pembelajaran mendatang.

\section{SIMPULAN}

Berdasarkan pemaparan di atas, dapat disimpulkan bahwa implementasi PDS melalui penerapan lesson study sangat efektif digunakan dalam mata kuliah Strategi, Metode, dan Media Pembelajaran. Lesson learn yang diperoleh adalah: 1) 
pemberian materi dengan media metode pembelajaran kolaboratif membuat pembelajaran yang tepat menjadi daya tarik mahasiswa belajar secara langsung sehingga tersendiri bagi mahasiswa, 2) pembentukan proses pemahaman lebih maksimal kelompok belajar memungkinkan diperoleh. Beberapa lesson learn yang mahasiswa untuk mengembangkan diperoleh menjadi indikator relevannya kemampuan kolaboratif dan komunikatif, 3) penerapan lesson study dalam mata kuliah pemberian tugas berupa video penerapan ini.

\section{DAFTAR RUJUKAN}

Direktorat Jendral Pembelajaran dan Kemahasiswaan Ristekdikti. (2019). Panduan Program Bantuan Penugasan Dosen di Sekolah. Jakarta: Kemenristekdikti.

Putra, Yukon dkk, (2010). Belajar dari Pembelajaran: Best Practice Implementasi Lesson Study. Jakarta: Direktorat Tenaga Kependidikan, Dirjen PMPTK Kementerian Pendidikan Nasional.

Ratnaningsih, D. (2018). IMPLEMENTASI LESSON STUDY DALAM MATA KULIAH ANALISIS KESALAHAN BERBAHASA UNTUK MENINGKATKAN KEMAMPUAN KOOPERATIF MAHASISWA SEMESTER VII STKIP MUHAMMADIYAH KOTABUMI. Edukasi Lingua Sastra, 16(1), 39-46.

Ratnaningsih, D., \& Septiana, S. (2019). PEMBELAJARAN KOLABORATIF PADA MATA PELAJARAN BAHASA INDONESIA DI SMK NEGERI 1 KOTABUMI. Edukasi Lingua Sastra, 17(1), 21-28.

Rusman. (2011). Model-model Pembelajaran: mengembangkan Prefesinalisme Guru. Jakarta: Rajawali Press

Sandi. (2010). Pengembangan Bahan Workshop Lesson study Serta Implementasi Oleh Guru Matematika di Madrasah Ibtidaiyah Negeri 1 Pangkalpinang. Tesis tidak diterbitkan. Palembang: Fakultas Keguruan dan Ilmu Pendidikan.

Susilo, Herawati. (2009). Lesson study Berbasis Sekolah" Guru Konservatif Menuju Guru Inovatif”. Malang: Bayumedia Publishing.

Widhiartha, Ashintya Putu dkk. (2008). Lesson Study: Sebuah Upaya Peningkatan Mutu Pendidik Pendidikan Nonformal. Surabaya: Prima Printing Surabaya. 